\title{
DIGITALCOMMONS
}

@WAYNESTATE-

Wayne State University

March 2020

\section{Total Knee Arthroplasty: Opioid-Free Analgesia in a Patient with Opioid-Induced Hyperalgesia}

\author{
Noel Akioyamen
}

gg5379@wayne.edu

Allen Kadado

Henry Ford Health System, akadado1@hfhs.org

Follow this and additional works at: https://digitalcommons.wayne.edu/som_srs

Part of the Medicine and Health Sciences Commons

\section{Recommended Citation}

Akioyamen, Noel and Kadado, Allen, "Total Knee Arthroplasty: Opioid-Free Analgesia in a Patient with Opioid-Induced Hyperalgesia" (2020). Medical Student Research Symposium. 36.

https://digitalcommons.wayne.edu/som_srs/36

This Research Abstract is brought to you for free and open access by the School of Medicine at DigitalCommons@WayneState. It has been accepted for inclusion in Medical Student Research Symposium by an authorized administrator of DigitalCommons@WayneState. 


\title{
Total Knee Arthroplasty: Opioid-Free Analgesia in a Patient with Opioid-Induced Hyperalgesia
}

\begin{abstract}
Case: Controlling pain in total knee arthroplasty (TKA) is important but can be complex. We present a case of a 59-year-old female with opioid-induced hyperalgesia who was referred for left knee pain and end-stage tricompartmental degenerative joint disease after failure of conservative management. We outline an approach to control postoperative pain in patients undergoing TKA who have severe opioid contraindications.

Conclusion: TKA and physical rehabilitation with a 2 year follow up period was accomplished using a multimodal non-opioid approach including a combination of gabapentin, acetaminophen, ketorolac, meloxicam, methocarbamol, a tunneled femoral nerve catheter, and peri-articular cocktail injection.
\end{abstract}

Key terms: Total knee arthroplasty, Opioid-free analgesia, Opioid induced hyperalgesia 